\title{
ドップラーソーダによる自然風観測值に基づく風速プロファイルの推定に関して EVALUATION OF WIND SPEED PROFILE FROM OBSERVATIONS BY DOPPLER SODARS
}

\author{
須田健一*1, 菅沼信也*2, 岩谷祥美*3, 佐々木 淳*4, 中村 修*5 \\ 丸山敬*6, 日比一喜*7, 石橋龍吉*8, 田村幸雄*9 \\ Kenichi SUDA, Shinya SUGANUMA, Yoshiharu IWATANI, Atsushi SASAKI, Osamu NAKAMURA, \\ Takashi MARUYAMA, Kazuki HIBI, Ryukichi ISHIBASHI and Yukio TAMURA
}

\begin{abstract}
Authors' group has been conducting full-scale measurements of atmospheric boundary layer wind speeds by doppler sodars. It is expected to obtain the wind speed profile easily by doppler sodars, because the wind speeds at many altitudes can be measured simultaneously. Preceding to the observation, the quality of the data obtained in various measuring conditions was studied, and the optimum measuring condition was shown. In our study, the measurements had been selected on the basis of the wind speed at the reference altitude, and wind speed profile had been evaluated from the averaged values of them. This method was reexamined by the statistical method in this paper. It is conformed that the value of wind speed at the reference altitude is overestimated in this method and suggested that the measurements would rather be selected by the wind speed averaged at whole altitudes. However, it was pointed out that the data collectable rate at higher altitudes reduced as the wind speed became higher. This phenomenon were presumed to be caused by wind-induced noise. In this paper, the effects of wind-induced noise on the data collectable rates and the measurements were also studied. It is confirmed that the effect of wind-induced noise cannot be ignored and the errors in the measurements are significant at higher altitudes.
\end{abstract}

Key Words : Doppler sodar, Wind speed profile, Natural wind observation, Statistical method, Wind-induced noise ドップラーソーダ, 風速プロファイル, 自然風観測, 集計方法, 風騷音

\section{1 はじめに}

建築物の耐風設計では，設計風速を正しく見積ること，すなわち， 地表面状態を考慮して風速を合理的に評価することが重要である。 しかし，そのための資料は十分ではなく，特に地上 $200 \mathrm{~m}$ を越える 高度での風速分,布や地表面粗度に応じた風速の増減に関する情報は 少ない。ドップラーソーダは, 高高度までの風速をほほ同時に測定 できるので, 風速のプロファイルが容易に得られるものと期待され ており，近年，これを用いた自然風の観測も多〈行われている1，2， 3)，4)な。筆者らのグループでも，複数のドップラーソーダを用いて， 地表面粗度の異なる複数地点における自然風の同時観測を続けてお り 5), それらの観測データから, 地表面粗度による風速の変化や風速 プロファイルの相違を見いだそうとしている。

しかし，ドップラーソーダによる自然風観測結果から風速プロフ アイルを求めようとする場合, ドップラーソーダの性能や自然風の
特性を考慮して，高高度まで観測できる適当な観測方法を定めるこ とと, 観測データの適切な評価方法を採用することが重要である。 ドップラーソーダの自然風観測への適用については文献 6)でも検討 されているが，このような目的に合った観測方法の指針は必ずしも 明らかではない。また，観測值から風速プロファイルを推定する方 法については，これまでに検討例は見当たらない。

本報は，ドップラーソーダによる自然風観測から風速プロファイ ルを推定する場合に問題となる点を検討し，適切な観測方法と評価 方法を見出そうとしたものである。まず，種々の観測条件による自 然風観測を行い, ドップラーソーダを用いて高高度までの自然風観 測を行うのに適切な観測条件を把握した。次いで, 時空間平均值と して観測されるドップラーソーダの観測值から風速プロファイルを 推定できるかどうかを，解析的に検討した。その際の測定高度の評 価についても検討している。また, 本研究では, 風速レベルごとに
*1 佐藤工業株中央技術研究所 主席研究員 - 工博

*2 東京工芸大学二..学部建築学科 講師. 工博

*3 日本大学生産工学部教授. 理博

*4 西松建設秼技術研究所研究員. 工蓚

*5 株)風工学研究所 所長. 工博

*6 京都大学防災研究所 助教授・工博

*7 清水建設(㑣)技術研究所 部長 - 工博

*8 都市基盤整備公団

*9 東京工芸大学:工学部建築学科 教授. 工博
Research Head, Engineering Research Institute, Sato Kogyo, Dr. Eng.

Lecturer, Dept. of Architecture, Faculty of Engineering, Tokyo Institute of Polytechnics, Dr. Eng.

Prof., College of Industrial Technology, Nihon University, Dr. Sci.

Research Engineer, Technical Research Institute, Nishimatsu Construction, M. Eng. Manager, Wind Engineering Institute, Dr. Eng.

Assoc. Prof., Disaster Prevention Research Institute, Kyoto University, Dr. Eng.

General Manager, Institute of Technology, Shimizu Corp., Dr. Eng.

Urban Development Corp.

Prof., Dept. of Architecture, Faculty of Engineering, Tokyo Institute of Polytechnics, Dr. Eng. 
多数の観測デー夕を集計して, 各高度の風速を評価する方法を採っ ているが，その際のデー夕選別方法による風速プロファイル推定結 果に及ほす影響を検討し，適切なデー夕選別方法を示した。また， 強風時ほど，デー夕の取得率が聥減し，観測可能な高度が下ること が指摘されている7が, その原因を風騒音に依るものと想定して，そ れが観測された風速プロファイルに及ぼす影響についても検討した。

\section{2 ドップラーソーダを用いた自然風観測方法の検討}

\section{1 ドップラーソーダを用いた自然風観測の原理と観則条件設 定上の問題}

本研究では，自然風観測にモノスタティック方式ドップラーソー ダ(AR-410 型（株カイジョー）を使用している。本方式の概念を図 1 に示寸。ドップラーソーダはあるパルス幅の送信信号からの後方 散乱波をある時間，受信した信号をもとに風速を推定するものであ る。ただし，モノスタティック方式は，3 方向の各ビームをある間隔 で順次，発信する方式である。

$$
\begin{gathered}
\text { ドップラーソーダの受信パワー } P_{r} \text { は (1) 式によって与えられる。 } \\
P_{r}=P_{r} \eta_{r} \eta_{r} \sigma(\pi) \cdot c \tau / 2 \cdot A_{r} L / R^{2} \quad \cdots \cdots(1)
\end{gathered}
$$

ここで, $P_{t}$ : 発信パワー, $\eta_{t}:$ 発信変換効率, $\eta_{r}$ : 受信変換効率, $\sigma(\pi)$ : 散乱断面積, $c$ : 音速 $(=340 \mathrm{~m} / \mathrm{s}$ と仮定 $), \tau$ : 発信パルス幅, $A_{r}$ : アンテナ有効面積, $R$ : 散乱大気層までの距離, $L:$ 音波の大気 による減衰率 である。高高度までのデー夕を取得するには受信波 のパワーを確保する必要があり，そのためには発信パワーP $P_{t}$ あい は発信パルス幅 $\tau$ を大くす机ば良い。一方，モノスタティック方 式ドップラーソーダにおける高度分解能は（2）式によって決まる ので，発信パルス幅 $\tau$ を増大させると高度分解能の低下につながる。

$$
\Delta h=c\left(\tau+\tau_{F}\right) / 4
$$

ここで， $\tau_{F}$ は 1 測定高度に対する受信時間である。

このため，本研究に使用するドップラーソーダでは，単一パルス 方式に加えて，低高度を短パルス（パルス幅 $\tau_{1}$ ) で, 高高度を長パ ルス（パルス幅 $\tau 2$ ）のビームで探査する，混合パルス方式が用意 されている。混合パルス方式の概念は図 2 に示した通りである。

本研究では地上高度 $500 \mathrm{~m}$ 程度までのデー夕取得を目指している が，どちらのパルス方式が適当か，パルス幅をどう取るか，予め検 討が必要である。また，送信波の周波数が高くなると距離減衰が大 きくなり，測定可能高度が低下寸る。こ北は現地の暗騒音にも左右 されるので，その大きさを考虑して，周波数と送信パワーを選択寸 る必要がある。本システムでは, 送信周波数は $1600,2400,3200 \mathrm{~Hz}$, 送信パワーは $150,400,900 \mathrm{~W}$ の 3 通りに変えることができる。

\section{2 ドップラーソーダの設定条件によるデータ取得率および風 速観測值への影䉕（予備観測結果）}

十分な高高度までの風速を取得するための観測条件を把握するた め, ドップラーソーダの設定条件（送信方式，パルス幅，送信パワ 一および送信周波数）を变えた場合の，デー夕取得率および観測值 への影響を、自然風の予備観測によって調べた。デー夕取得率とは 10 分間の観測数に占める有効観測数の割合と定義され，本観測では

（3）式で定義する $\gamma$ が $10 \mathrm{~dB}$ 以上のものを有効観測としている。

$$
\gamma=S\left(f_{p}\right) /\left\{\sum_{i=1}^{n} S(f) / n\right\}
$$

ここで, $S\left(f_{P}\right)$ は受信波のピークのパワースペクトル, $\sum_{i=1}^{n} S(f) / n$ は送信周波数士 $10 \%$ の周波数間の受信波の平均パワーである。観測 場所は住宅地であり，東側を国道が通っている。観測時間は昼間で， 天気は晴れまたは薄暈りであった。観測は，各ケースとも平均化時 間を 10 分間, 観測回数を各 3 回とし，連続した時間帯に行った。

（1）単一パルス方式の場合 送信周波数を $2400 \mathrm{~Hz}$, 送信パワー を $900 \mathrm{~W}$ とし，パルス幅を変えた場合について検討した。各高度で の水平方向探査用のビーム A および B のデー夕取得率を, 各観測ご とにプロットしたものを図 3 に示した。なお，デー夕取得率が $30 \%$ 程度末満の場合には，特異な風速が得られる場合があり，10 分間平 均風速としても不適切なデー夕になる恐㣗があると考えら机る。

図 3 に示す結果から，主として次の 3 点が確認できた。(1) $400 \mathrm{~m}$ 以上の高度までのデータを得るには，パルス幅を $200 \mathrm{~ms}$ より大きく する必要がある。一方, 高度 $100 \mathrm{~m}$ 以下のデー夕を取得するのは難 しくなる。(2)高度 $200 \mathrm{~m}$ 程度以下のデー夕を得るには，パルス幅を $100 \mathrm{~ms}$ 以下とする必要がある。(3したがって, 高度 $500 \mathrm{~m}$ までの範 囲のデー夕を得るには，単一パルス方式では困難なようである。

（2）混合パルス方式の場合 パルス幅を低高度用 $50 \mathrm{~ms}$, 高高度 用 $300 \mathrm{~ms}$ とし，送信周波数と送信パワーを変えた場合の観測結果を 図 4 に示した。図中, $U, \sigma u$ は水平主流方向の平均風速, 標準偏差 (本システムによる推定值)である。送信周波数 $1600 \mathrm{~Hz}$ の場合（図 4 (a))，デー夕取得率は高度 $100 \mathrm{~m}$ 以下および $300 \mathrm{~m}$ 以上では極め て小さい。送信パワーを最大の $900 \mathrm{~W}$ としているが, 取得率の大き い中間高度でも，高々 $50 \%$ 程度である。送信周波数 $3200 \mathrm{~Hz}$ の場合 (図 4 (b)) は, デー夕取得率は低高度では大きくなるが, 高度 $200 \mathrm{~m}$ 以上では $50 \%$ を割り，高度の增加とともに急減し， $300 \mathrm{~m}$ 以上では 極めて小さくなる。送信パワーを大きくしても，300m 程度までが限 界のようである。 $2400 \mathrm{~Hz}$ (図 4 (c),(d)) では, デー夕取得率の大き な範囲が低高度からかなり高高度まで及ぶようになり，特に送信パ ワーを 900W にした図4 (d)では観測值もよくまとまっている。ただ し, $500 \mathrm{~m}$ からはデー夕取得率が急減しており，この高度か測定の限

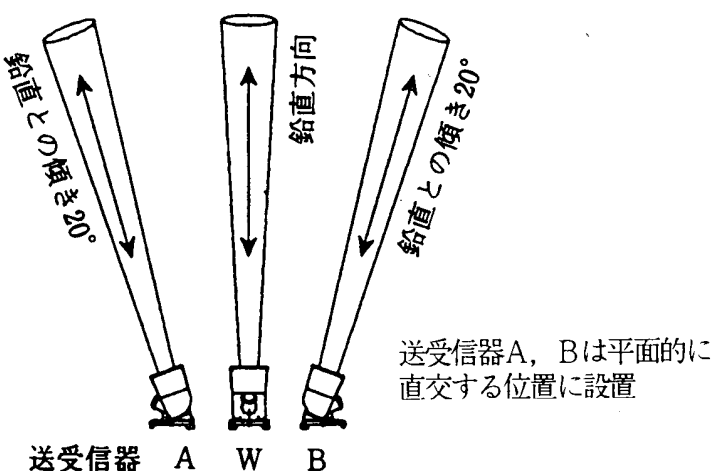

図 1 モノスタティック方式ドップラーソータの観測原理

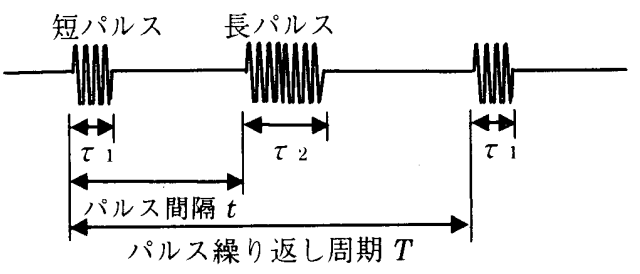

図 2 湦合パルス方式の概念 


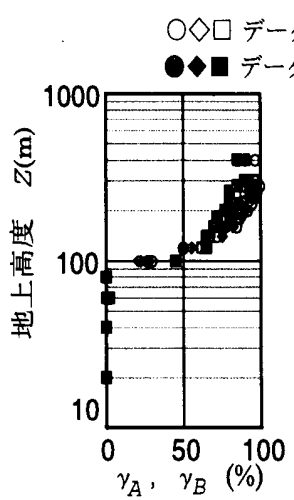

(a) $500 \mathrm{msec}$

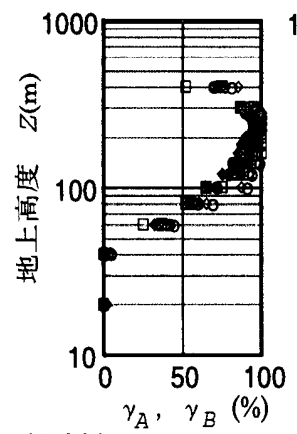

(b) $200 \mathrm{msec}$

(d) $50 \mathrm{msec}$

図3単一パルス方式の場合のパルス幅による テータ取得率の相違

（送信周波数 $2400 \mathrm{~Hz}$. 送信パワー900W）

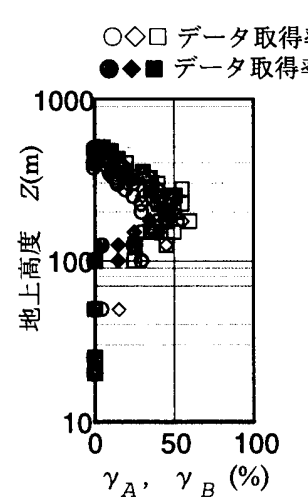

(a) 送信周波数 $1600 \mathrm{~Hz}$ 送信パワー 900W

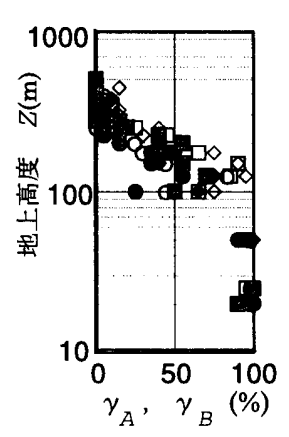

(b) 送信周波数 $3200 \mathrm{~Hz}$ 送信パワー $400 \mathrm{~W}$

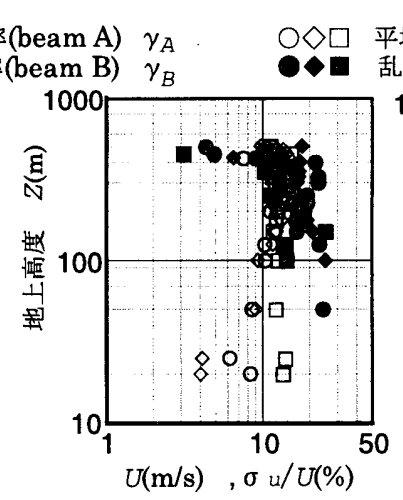

（c）送信周波数 $2400 \mathrm{~Hz}$ ，送信パワー $400 \mathrm{~W}$
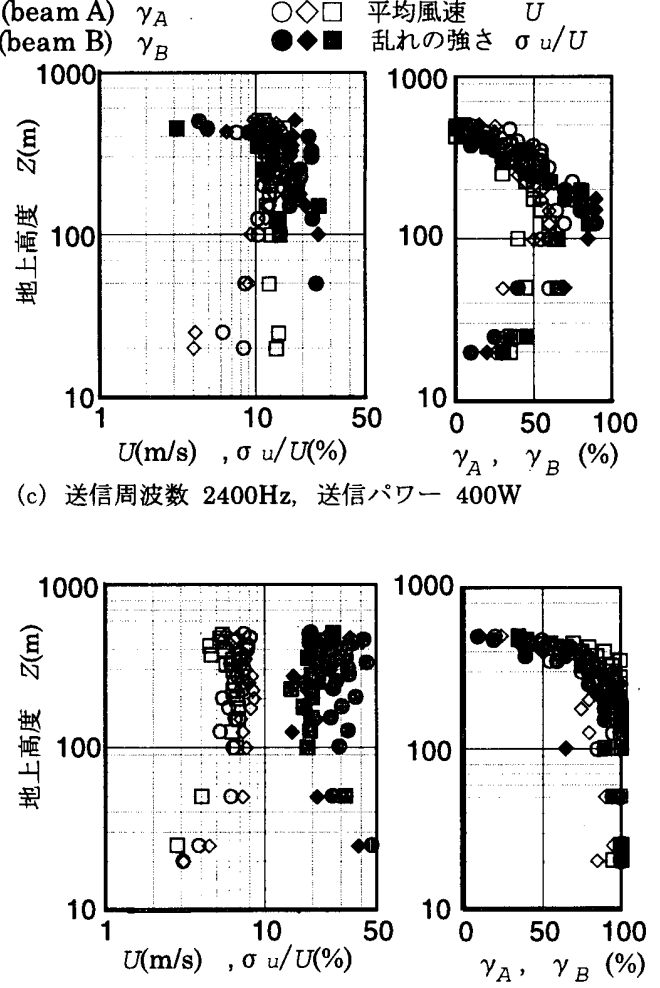

（d）送信周波数 $2400 \mathrm{~Hz}$ ，送信パワー $900 \mathrm{~W}$

図4混合パルス方式の場合の観測条件によるデータ取得率, 観測値の相違 (混合パルス：低高度用 $50 \mathrm{~ms}$, 高高度用 $300 \mathrm{~ms}$ )

界であると考えられる。この結果から，パルス幅を低高度用 $50 \mathrm{~ms}$ ， 高高度用 $300 \mathrm{~ms}$ とした場合は，高度 $500 \mathrm{~m}$ 程度までを測定対象とす ると，送信周波数は $2400 \mathrm{~Hz}$ が最も適当であることが分かる。この

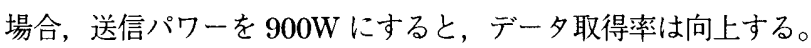

上述の観測結果を踏まえ，また，予備観測時に比べて，強風時に は $\mathrm{S} / \mathrm{N}$ 比が低下寸る可能性が大きいことを考慮して, 本研究では以 下のような観測条件とすることとした。

·発信周波数 : $2400 \mathrm{~Hz}$

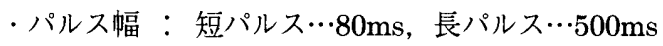

・測定高度 ：短パルス $\cdots 40 \sim 100 \mathrm{~m}$ ，長パルス $\cdots 110 \sim 1100 \mathrm{~m}$ ・受信時間 : $107 \mathrm{~ms}$

・高度分解能 : 短パルス $\cdots 19.125 \mathrm{~m}$, 長パルス $\cdots 54.825 \mathrm{~m}$

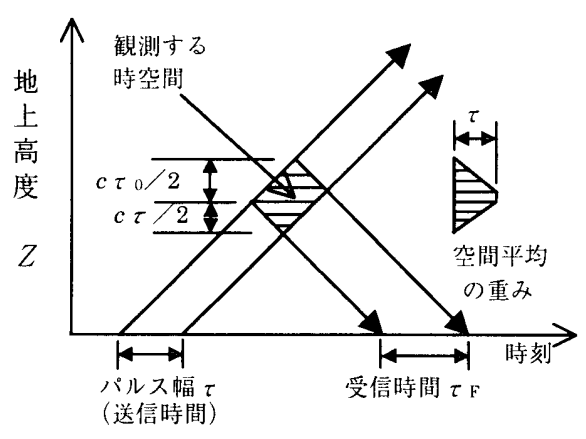

図 5 ドップラーソーダによる観測值の時空間平均の概念 (単一ビームと仮定)
3 ドップラーソーダによる自然風観測值についての検討

3. 1 ドップラーソーダによる平均風速の空間平均について

ここでは, 簡単のため, ドップラーソーダからの送信波を単一ビ 一ム之仮定して検討する。その概念は図 5 に示すようになる。した がって, 他の要因の影響を除いて単純化して考えると, ドップラー ソーダにおける観測值は, 図 5 に示寸時空間からの情報に基づくも のであり，図 $5 に$ 示す重み付き空間平均を求めていることになる。 このような観測值から風速プロファイルが得られるかを検討した。

ここでは, 水平風速のプロファイルがべき法則に従うと仮定し、 各高度における風速を上記の重み付き空間平均値として算出し, こ

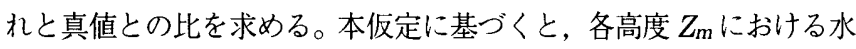
平風速の重み付き空間平均值 $U_{m}$ は ( 4 )式で求めることができる。
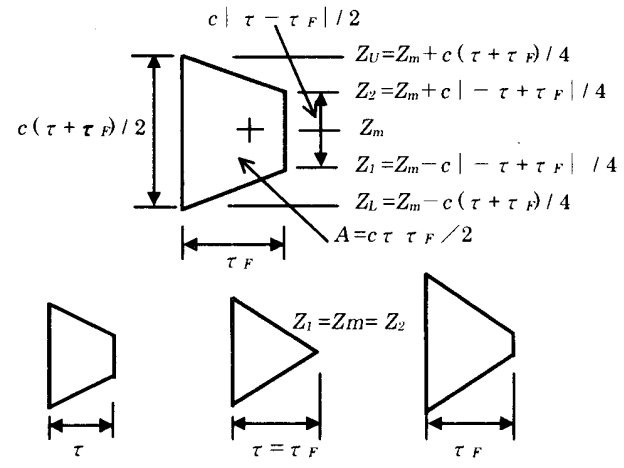

(a) $\tau<\tau F$ の場合 $\quad(b) \tau=\tau_{F}$ の場合 $\quad(c) \tau>\tau_{F}$ の場合 図 6 空間平均の重み関数 $W z$ 


$$
U_{m}=\int_{Z_{t}}^{Z_{t}} U_{Z} \cdot W_{Z} d Z=\int_{Z_{l}}^{Z_{l t}} U_{Z_{m}}\left(Z / Z_{m}\right)^{\alpha} \cdot W_{Z} d Z \cdots
$$

ただし， $U_{Z}$ ：地上高度 $Z(\mathrm{~m})$ における平均風速 $(\mathrm{m} / \mathrm{s})$

$$
\left(=U_{Z_{m}}\left(Z / Z_{m}\right)^{a}\right)
$$

$U_{Z_{m}}:$ 地上高度 $Z_{m}(\mathrm{~m})$ にお沙る平均風速 $(\mathrm{m} / \mathrm{s})$

$\alpha:$ 水平風速プロファイルのべき指数

$W_{Z}$ ：地上高度 $Z(\mathrm{~m})$ における空間平均の重み関数

$Z_{U}, Z_{L}:$ 空間平均の上限高度および下限高度

空間平均の重み関数 $W_{Z}$ は, パルス幅 $\tau に$ 依存し，受信時間 $\tau F$ に対 する長短によって，図6のようになる。

各高度 $Z_{m}$ における水平風速の重み付き空間平均值 $U_{m}$ と真の値 $U Z m$ との比を算定した結果を表 1 に示した。低高度や発信パルス幅 が大きくなった場合には，若干，真值とは外れるが，ほほ真値に近 い值が得ら扎るものと判断できる。したがって，十分な精度で，高 高度までの観測值が得られれば，ドップラーソーダによる観測によ って，風速プロファイルを推定することは可能であると考えら札る。

\section{2 ドップラーソーダの測定高度について}

3.1節では, 音波の距離減衰を無視して検討を行った。しかし, ドップラーソーダの受信パワーは音波の散乱領域までの距離の 2 乗 に反比例するので，広い散乱領域からの散乱波を受信した場合には， 受信波は対象領域内の低高度からの散乱波の影響をより強く受ける ことになる。このことを考慮すると，測定高度の設定は見直す必要 があるものと考元ら机る。本節では，音波の距離減衰を考慮した場 合，実質的な測定高度がどのように評価されるかを検討した。

\section{（1）ドップラーソーダの測定高度について}

（1）式の分子の各項を時間と高度に依存しない定数であると仮 定すると，以下のように書き換えることができる。

$$
P_{r}=B \cdot c \tau / 2 Z^{2}
$$

ただし，Bは定数であり， $B=P_{t} \eta_{t} \eta_{r} \sigma(\pi) \cdot A_{r} L$ である。

微小時間 $\mathrm{d} \tau$ 間の発信パルスに対する, 高度 $Z$ からの後方散乱で得 られる受信パワーへの寄与分を $\mathrm{d} P_{\mathrm{r}}$ とすると，（6）式が成立する。

$$
d P_{r}=\left(B \cdot c / 2 Z^{2}\right) \cdot d \tau
$$

図7のように時刻 $t_{0}$ に長さ $\tau$ のパルスが発信されたとき, 時刻 $t_{A}$ に おける受信パワー $P_{r}$ は, $Z=c\left(t_{A^{-}}-t\right) / 2, d Z=-(c / 2) \mathrm{d} \tau, Z_{1}=c\left(t_{A}\right.$

\begin{tabular}{|c|c|c|c|c|c|c|c|c|}
\hline & \multicolumn{7}{|c|}{ パルス幅 $\tau(\mathrm{ms})$} \\
\hline & & $1 / 2 \tau_{F}$ & $\tau_{F}$ & $3 / 2 \tau$ & $2 \tau F$ & $5 / 2 \tau_{H}$ & $3 \tau_{H}$ & $7 / 2 \tau_{F}$ \\
\hline 測 & $c \tau t$ & 0.998 & 0.997 & 0.995 & 0.993 & 0.989 & 0.983 & 測定不矿 \\
\hline 分: & $2 c \tau_{F}$ & 1.000 & 0.999 & 0.999 & 0.998 & 0.998 & 0.997 & 0.997 \\
\hline 高 & $3 c \tau F$ & 1.000 & 1.000 & 1.000 & 0.999 & 0.999 & 0.998 & 0.998 \\
\hline 度 & $4 c \tau F$ & 1.000 & 1.000 & 1.000 & 1.000 & 0.999 & 0.999 & 0.999 \\
\hline$Z$ & $5 c \tau r$ & 1.000 & 1.000 & 1.000 & 1.000 & 1.000 & 1.000 & 0.999 \\
\hline (m) & $6 c \tau F$ & 1.000 & 1.000 & 1.000 & 1.000 & 1.000 & 1.000 & 1.000 \\
\hline
\end{tabular}
$\left.-t_{0}\right) / 2, Z_{2}=c\left(t_{A^{-}} \tau-t_{0}\right) / 2$ であるので，(7)式となる。
表 1 ドップラーソーダによる水平風速観測值 / 真值 $\left(U_{m} / U_{\mathrm{Zm}}\right)$

\begin{tabular}{|c|c|c|c|c|c|c|c|c|}
\hline & \multicolumn{7}{|c|}{ パルス幅 $\tau(\mathrm{ms})$} \\
\hline & & $1 / 2 \tau_{F}$ & $\tau F$ & $3 / 2 \tau r$ & $2 \tau F$ & $5 / 2 \tau_{F}$ & $3 \tau F$ & $7 / 2 \tau_{F}$ \\
\hline 測 & $c \tau F$ & 0.997 & 0.995 & 0.992 & 0.988 & 0.982 & 0.972 & 測定不河 \\
\hline 筆 & $2 c \tau F$ & 0.999 & 0.999 & 0.998 & 0.997 & 0.996 & 0.994 & 0.992 \\
\hline 高 & $3 c \tau F$ & 1.000 & 0.999 & 0.999 & 0.999 & 0.998 & 0.998 & 0.997 \\
\hline 度 & $4 c \tau F$ & 1.000 & 1.000 & 1.000 & 0.999 & 0.999 & 0.999 & 0.998 \\
\hline$Z$ & $5 c \tau F$ & 1.000 & 1.000 & 1.000 & 1.000 & 0.999 & 0.999 & 0.999 \\
\hline (m) & $6 c \tau F$ & 1.000 & 1.000 & 1.000 & 1.000 & 1.000 & 0.999 & 0.999 \\
\hline
\end{tabular}

(a) べき指数 $\alpha=0.15$ の場合

（b）べき指数 $\alpha=0.30$ の場合

$$
\begin{aligned}
P_{r} & =\int_{t_{0}}^{t_{0}+\tau} d P_{r}=\int_{Z_{1}}^{Z_{2}}\left(-B / Z^{2}\right) d Z=B\left(1 / Z_{2}-1 / Z_{1}\right) \\
& =B c \tau / 2 Z_{1} Z_{2} \quad \ldots \ldots \ldots \ldots \cdots \cdots
\end{aligned}
$$

(5)式と $\left(7\right.$ )式を比較すると, 時刻 $t_{A}$ における受信パワーの測定高度 は, $\left(Z_{1}+Z_{2}\right) / 2$ ではなく,

$$
Z=\sqrt{\left(Z_{1} \cdot Z_{2}\right)}
$$

とするのが合理的であることが分かる。この両者の差は $Z_{1}$ と $Z_{2}$ の大 きさとその差に依存し，その差は発信パルス長に依存する。

ドップラーソーダは受信時間 $\tau F$ の間, 連続的に信号を受信する。

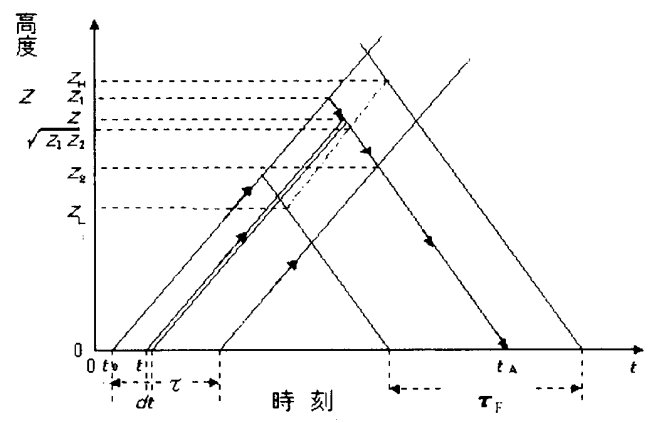

図 7 ドップラーソーダの観測高度
表2 測定高度の補正値

\begin{tabular}{|c|c|c|c|c|c|}
\hline $\begin{array}{c}\text { 測定 } \\
\text { 高度 } \\
(\mathrm{m})\end{array}$ & $\begin{array}{c}\text { 補正 } \\
\text { 高度 } \\
(\mathrm{m})\end{array}$ & $\begin{array}{c}\text { 測定 } \\
\text { 高度 } \\
(\mathrm{m})\end{array}$ & $\begin{array}{c}\text { 補正 } \\
\text { 高度 } \\
(\mathrm{m})\end{array}$ & $\begin{array}{c}\text { 測定 } \\
\text { 高度 } \\
(\mathrm{m})\end{array}$ & $\begin{array}{c}\text { 補正 } \\
\text { 高度 } \\
(\mathrm{m})\end{array}$ \\
\hline 40 & 39.4 & 160 & 154.2 & 460 & 458.0 \\
50 & 49.5 & 180 & 174.9 & 500 & 498.2 \\
60 & 59.6 & 200 & 195.4 & 550 & 548.4 \\
70 & 69.7 & 220 & 215.8 & 600 & 598.5 \\
80 & 79.7 & 250 & 246.4 & 650 & 648.6 \\
90 & 89.7 & 280 & 276.7 & 700 & 698.7 \\
100 & 99.8 & 310 & 307.1 & 750 & 748.8 \\
110 & 101.3 & 340 & 337.3 & 800 & 798.9 \\
120 & 112.1 & 380 & 377.6 & 900 & 899.0 \\
140 & 133.3 & 420 & 417.8 & 1000 & 999.1 \\
\hline
\end{tabular}

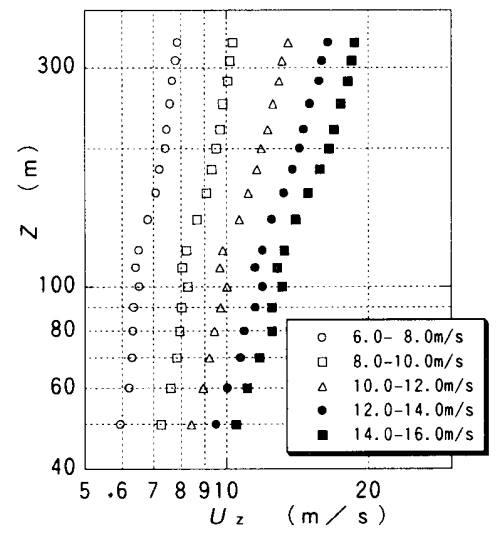

図8 ドップラーソーダによる風観測 結果より求めた風速プロファイル

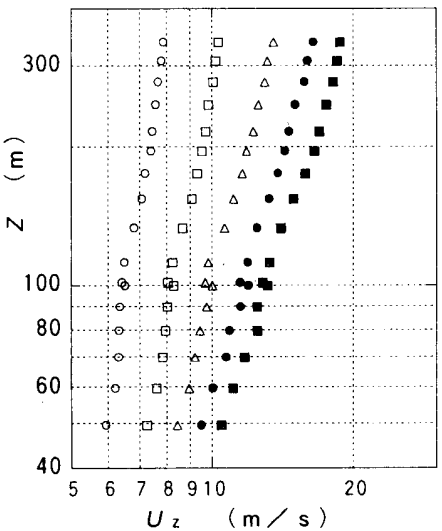

図 9 高度補正後の風速プロファイル 
各瞬時の受信信号に対応する高度は刻々変化する。したがって，各 瞬時の受信信号に対応する高度を上記の方法で求めて、その平均值 を受信時間 $\tau F$ 間の観測の測定高度とすることが合理的である。

本研究では，混合パルス方式を用いるが，たとえば，図 8 に示し た例のように，観測結果には，長パルスと短パルスのつなぎの高度

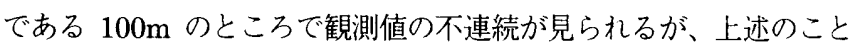
をこのような問題の生じる一因として考えることができる。特に大 きなシアーのある時に，不連続が大きくなっている。

\section{(2) 測定高度の補正}

発信パルス幅を小さくすると, 測定領域が狭くなり, 高度分解能 が良くなる。一方，発信パルス幅を大きくするとデー夕取得率を向 上させることができる。それぞれの長所を生か寸ために，低高度を 短パルス, 高高度を長パルスで測定するのが混合パルス方式である。 前述の本研究での測定条件に対する測定高度の補正值を表 2 に示 した。長パルスでの測定高度範囲の内，低高度に対する高度補正量 が大きくなっている。

\section{（3）測定データの解析例とその測定高度}

図 8 に示した結果を表 2 の値を用いて測定高度補正した結果を図 9 に示した。測定高度補正により風速プロファイルは幾分滑らかに なり，まだ完全な補正にはなっていないが，不連続がある程度は解 消されている。

\section{4 風速レベル別風速プロファイルに及ぼすデータ選別方法の影留}

ドップラーソーダで計測された各高度の 10 分間平均風速から, 風 速プロファイルを評価するに当たり，本研究では，各時刻ごとのプ

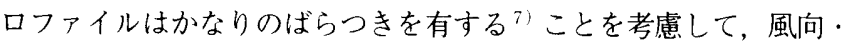
風速により選別したデータから，風向および風速レベル別にアンサ ンブル平均を取る方法を採用してきだ!。しかしながら、データの 選別を代表高度の風速によって行うとすると，条件付き期待値の考 えに基づけば, 得られる風速プロファイルは代表高度 $Z_{R}$ のとり方に 依存することが予想される。ここでは，代表高度での風速によって 選別することが風速プロファイルの推定に及ぼす影響を明らかにし， 風速レベル別の風速プロファイルを集計する方法について検討した。

\section{1 風速レベル別風速プロファイルの推定}

風速プロファイル $u_{Z}$ の標本が多数得られているとき, 代表高度 $Z_{R}$ での風速 $u_{R}$ が $u^{*}$ となる場合を選択して平均し, 風速レベル別の 風速プロファイル $U Z^{*}$ を求めることを考える。ここで, $u_{Z}$ が (9)
式のように同時正規分布に従うものとする。

$$
\left[\begin{array}{l}
u_{Z} \\
u_{R}
\end{array}\right] \approx N\left(\left[\begin{array}{l}
U_{Z} \\
U_{R}
\end{array}\right],\left[\begin{array}{cc}
\sigma_{Z}^{2} & \gamma_{Z R} \sigma_{Z} \sigma_{R} \\
\gamma_{Z R} \sigma_{Z} \sigma_{R} & \sigma_{R}^{2}
\end{array}\right]\right)
$$

ここで, $U_{Z}, \sigma_{Z}$ はそれぞれ $\mathrm{u}_{Z}$ の平均值および標準偏差, $U_{R}, \sigma_{R}$ はそ狆ぞ扎 $u_{R}$ の平均值および標準偏差, $\gamma Z R$ は $u_{Z}$ と $u_{R}$ の相関係 数である。また, $N(\mu, \Xi)$ は平均值べクトル $\mu$, 共分散行列 $の$ 正規分布に従うことを表している。同時正規分布の性質より，UZ* 条件付き期待值として（10) 式で推定される。

$$
U_{z}=U_{Z}+\frac{\gamma_{Z R} \sigma_{z}}{\sigma_{R}}\left(u^{\cdot}-U_{R}\right)
$$

\section{2 指数モデルを用いた考察}

はじめに非常に簡単なモデルを用いて集計方法の影響について検 討する。ここでは（１１１）式のような指数モデルを考える。

$$
\frac{U_{Z}}{U_{R}}=\left(\frac{Z}{Z_{R}}\right)^{\alpha}, \frac{\sigma_{Z}}{\sigma_{R}}=\left(\frac{Z}{Z_{k}}\right)^{\beta}
$$

上式を（1０）式に代入す机ば，直ちに（1 2) 式を得る。

$$
U_{Z}:=U_{Z}+\gamma_{Z R}\left(\frac{Z}{Z_{R}}\right)^{\beta}\left(u^{*}-U_{k}\right)
$$

（1２）式の右辺第 2 項が, 真の風速プロァイル $U_{Z}$ からの歪みを 表わしている。

べき指数 $\alpha, \beta$ ，相関係数 $\gamma Z R$ およよ゙デー夕選別風速 $u^{*}$ を以下 のように仮定した $U_{Z}^{*}$ の計算例を図 10 に示した。

$$
\begin{aligned}
& \left.\begin{array}{l}
\alpha=0.1, \beta=-0.05 \\
\gamma_{Z R}=\exp \left(-\frac{\left|Z-Z_{k}\right|}{K}\right), u^{*}=1.5 U_{R}
\end{array}\right\}
\end{aligned}
$$

ここで，Kは平均風速 $u_{Z}$ の $Z_{R}$ 付近での鉛直方向の相関長に相当す る。図からわかるように，通常の場合のような相関を仮定した $K=$ $200 \mathrm{~m}$ の場合には, 代表高度 $Z_{R}=100 \mathrm{~m}$ で極大值を持つプロファイ ルが得られる。こ机は，（13）式のように選別風速 $u^{*}$ として代表 高度での平均風速 $U_{R}$ より大きな值を仮定したからである。 $U_{R}$ より 小さな值を仮定す机ば， $U^{*}-U_{R}<0$ となり，（1 2 ）式から推定で きるように, $Z_{R}=100 \mathrm{~m}$ で極小值を持つような分布となる。（1 2 式から分かるように, この傾向は鉛直方向の風速の相関係数 $\gamma Z R$ が 大きくなる程，つまり，相関長 $K$ が小さくなる程，顕著になる。

なお，当然のことであるが，完全相関 $(\gamma z R=1, K=\infty)$ の場合

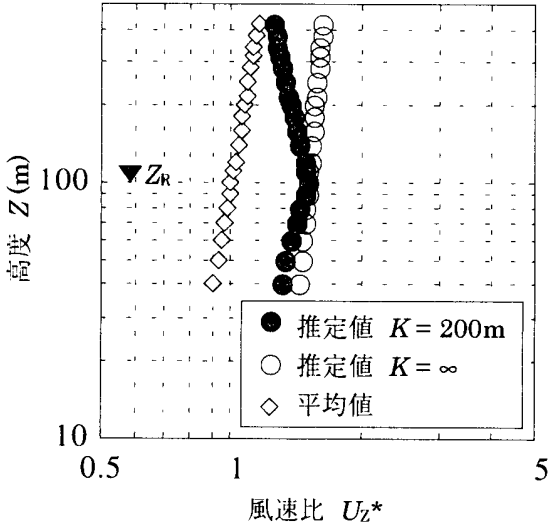

図 10 指数モテルを用いた選別集計の例

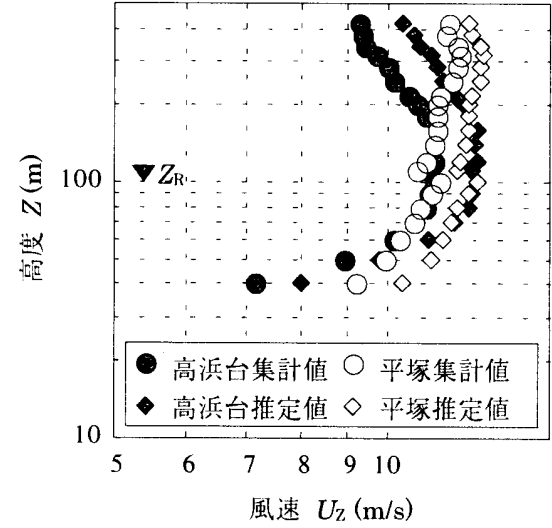

図１１代表高度で選別集計した風速プロ

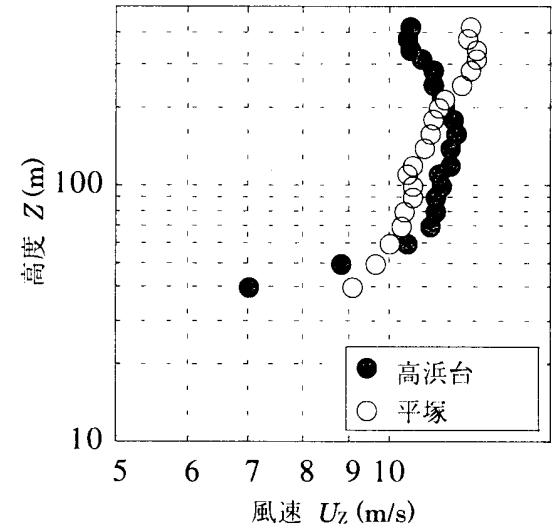

図 12 全高度の平均風速で選別集計した 風速プロファイル 
も真の平均風速プロファイルと同じ指数勾配のプロファイルにはな らない。この例のように $u^{*}>U_{R}$ の場合， $\alpha>\beta$ の時は真の平均風 速プロファイルのべき指数 $\alpha$ よりも小さい勾配になり, 反対に $\alpha<$ $\beta$ 時は真の平均風速プロファイルのべき指数 $\alpha$ よりも大きい勾 配のプロファイルを推定することになる。 $U^{*}<U_{R}$ の場合は逆になる。

\section{3 実測値による検討}

ドップラーソーダで実測された 10 分間平均風速のプロファイル を標本 $u_{Z}$ として，同様の検討を行う。ここでは代表高度での風向が 南となるデー夕を対象とし，「高浜台観測点」か门の 985 標本および 「平塚観測点」9)の 1806 標本を用いた。このような標本群から，風 速レベル別集計の例として, 代表高度の風速が $10 \leqq u_{R}<15 \mathrm{~m} / \mathrm{s}$ とな る標本を選別して集計した結果が図 11 である。図中には， $u^{*}$ $=12.5 \mathrm{~m} / \mathrm{s}$ とし, $\quad(12)$ 式に $U Z, \sigma Z, \gamma Z R$ の観測値を代入して 求めた推定值も併せて示した。いず狆の観測点でも集計值と推定值 の傾向は良く一致しており，（1 2）式による推定は概ね成立する ことが分かる。高浜台では, 図 10 の数值例と同様に, 代表高度付 近で最大值を持つプロファイルとなっており, 集計方法の影響が大 きく現机ていると見られ，真のプロファイルから歪んでしまってい ると考えられる。平塚についても高高度における風速の減少傾向を みてとることができる。

\section{4 観測值の集計方法の提案}

以上のように，特定の代表高度での風速によりデー夕を選別する 方法は，真のプロファイルから歪んだプロファイルを推定する恐れ があり，強風時の風速プロファイルを集計する方法として適切では ない。従来は代表高度 $Z_{R}=100 \mathrm{~m}$ をはさむ高度 $50-180 \mathrm{~m}$ の平均風 速により選別を行ってきだ。この方法ではかなりの高度領域での 平均値をとっているので, 前述の図10のような極端な歪みはない ものと思わ扎るが，より慎重を期して，本研究では全高度の平均風 速による選別をすることとした。図 12 は観測している全高度（高 度 $420 \mathrm{~m}$ まで) の平均風速が $10 \mathrm{~m} / \mathrm{s}$ 以上となる標本を選別集計して 得ら札た風速プロファイルである。

\section{5 推定される平均風速プロファイルに及ぼす風騒音の影曊}

ドップラーソーダによる風観測結果から，強風時ほど，データ取 得率が聥減し，観測可能な高度が下ることが指摘されており ${ }^{71}$ ，観 測された風速プロファイルへの影響が䀣念される。取得率低減の原 因として容易に想起できるのが，風速に伴って増加すると予測され る風騒音である。ここでは, ドップラーソーダのデー夕取得や観測 值への風騒音の影響について検討を試みた。推論を容易にするため にいくつかの仮定や簡略化を行っているが, 本論の主旨を歪めるも のではないことは，ある程度の幅を持った考察により確かめている。

\section{1 風速によるデータ取得率の変化}

海岸における自然風観測結果》から，各観測高度におけるデー夕 取得率 $\beta$ の出現確率を風速レベルごとにまとめたものを, 図 13 に 示した。なお，ここでは, 風速のレベル分けはデー夕取得率の大き い高度 $110 １ 40 \mathrm{~m}$ 間の平均風速によっている。

図13によると，高度とともにデー夕取得率が聥減することのほ かに, 風速が増す程, 全高度に渡って取得率が低下し, 特に高高度 では取得率の低減が大きいことが分かる。これまで，超音波風速計 との比較観測によって，ドップラーソーダでは $20 \%$ 以上の取得率が あれば，ほぼ真值に近似する観測值が得られるい!とされ，多くの観 測でもこれを基準に観測データが纏められている。ノイズがランダ ムに生じるのであ机ば，このように求めた期待值は真值に近似する と期待できる。しかし, 図 13 の結果は, 何らかの系統的なノイズ が影響していることを示唆している。文献 6 ）は，高度 $200 \mathrm{~m}$ まで の範囲での比較観測によって, ドップラーソーダの観測精度を検討 しているもので，より高高度については確認されておらず，上記の ようなデー夕の扱い方では，推定される風速プロファイルにもこれ らのノイズが影響を及ばす可能性が危惧される。

\section{2 ドップラーソーダによる観測と風騒音の関わり}

ドップラーソーダでは，送信波の後方散乱波を次々と受信するこ とによって，上空までの風速の情報を得ている。したがって，ドッ プラーソーダによる観測中は，目的の後方散乱波とともに，常に地 表付近から上空までの風騒音も同時に受信している（図１４）。観 測対象を高高度までとしても, 1 回の観測の所要時間は数秒であるの で，この間，平均風速プロファイル等に変化がないと考えて，各観 測対象高度の受信波中の風騒音のパワーは一定と考えることとし，

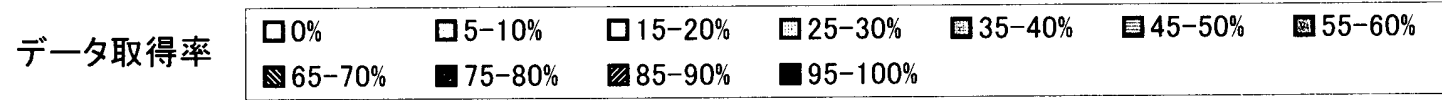

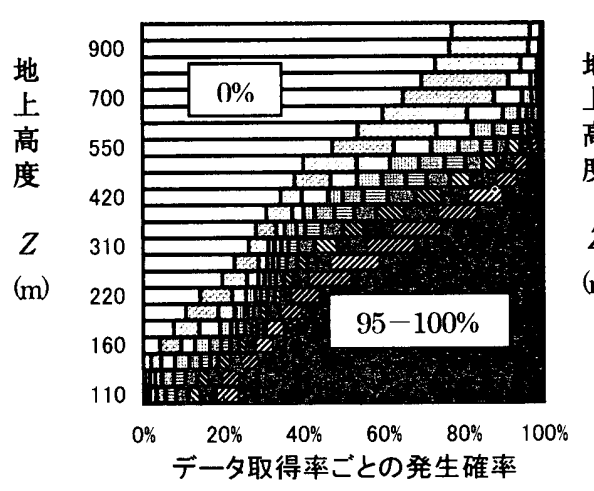

(a) $5 \leqq U<10 \mathrm{~m} / \mathrm{s}$ (データ数 1555)

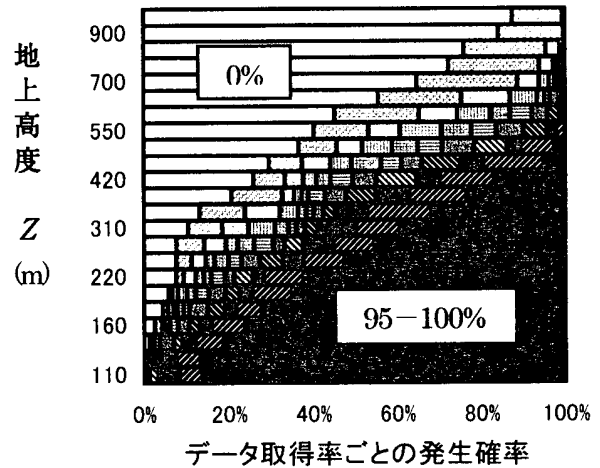

(b) $10 \leqq U<15 \mathrm{~m} / \mathrm{s}$ (デー夕数 327)

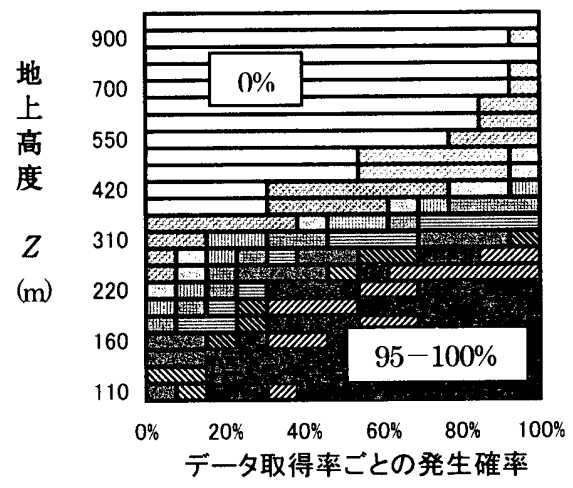

(c) $15 \leqq U<20 \mathrm{~m} / \mathrm{s}($ データ数 13 )

図 13 風速レベルごとのデータ取得率の出現確率の高度変化 (高浜台, アンテナ $\mathrm{A}$ (東向き), 風向：南) 


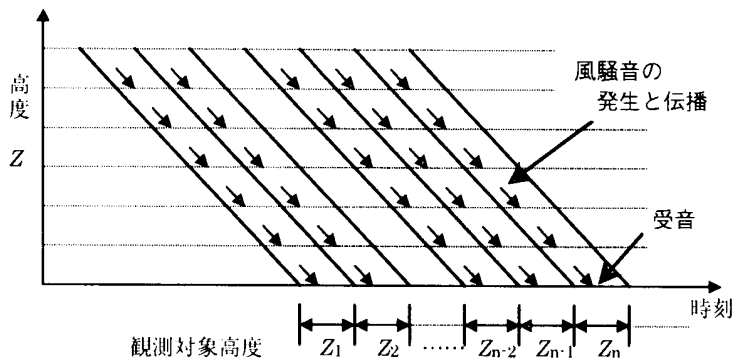

図14 風騷音の発生・伝播と受音

また，風騒音の発生源には様々のものを想定しうるが，ここでは簡 単に，そのパワーは(14)式で表さ机る(1)と考えることにする。

$$
P_{W}=C \times U^{n}
$$

ここで, $U$ は任意の基準高度での風速である。定数 $C$ は観測地の条 件が定まれば，䖝向，すなわち，風速プロファイルのみに依存する。 したがって，風向を限れば，風騷音の大きさは風速のみに依存して 増加することになる。

\section{3 データ取得可能な限界風速}

ドップラーソーダの受信波のパワーを，図１5に示すように，後 方散乱波, 暗騒音 (風騒音を含まない) と風騒音に分離して考えると,

$$
\gamma_{Z}=\left\{S_{Z}\left(f_{P}\right)+N_{B}+N_{W}\right\} /\left\{N_{D, Z}+N_{B}+N_{W}\right\} \cdots \cdots \text { (1 } 5 \text { ) }
$$

ここで, $S_{Z}\left(f_{p}\right)$ は高度 $Z$ での後方散乱波のピークのパワースペク トル， $N_{D, Z}, N_{B}, N_{W}$ はそ扎ぞ後方散乱波，暗騒音，風騒音の平 均パワーである。なお，対象帯域 $f_{1} \sim f_{N}$ は狭く，その間の風騒音の パワーは, 周波数に依る変化が小さいと考えられるので,ここでは, 周波数に依らず一定と仮定して検討する。

風速 $0 \mathrm{~m} / \mathrm{s}$ の時, 高度 $Z_{\max }$ までデー夕取得可能であるとし, $N_{D, Z \max }=d \cdot S_{Z \max }\left(f_{P}\right), N_{B}=b \cdot S_{Z \max }\left(f_{P}\right)$ とおくと, 有効観測を $\gamma \geqq 10$ としているので，(16)式が導か机る。

$$
\begin{aligned}
\gamma_{Z \max } & =\left\{S_{Z \max }\left(f_{P}\right)+N_{B}\right\} /\left\{N_{D, Z \max }+N_{B}\right\} \\
& =(1+b) /(d+b)=10
\end{aligned}
$$

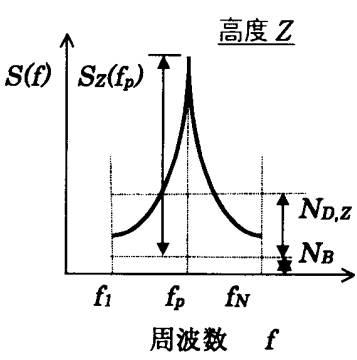

（a） 風馶音の影響のない場合

図 15 受信波のパワー・スペクトル

である $\left(N_{D, Z}=d \cdot S_{Z}\left(f_{P}\right)\right)$ とし，音波の距離隇衰を考慮すると， (1 7 ) 式が成立する。

$$
S_{Z}\left(f_{P}\right)=S_{Z \text { max }}\left(f_{P}\right)(Z / Z \max )^{-2}, N_{D, Z}=N_{D, Z \max }(Z / Z \max )^{-2}
$$

したがって，風騒音が加わった場合のデー夕取得条件は，（16） 式を考慮すると，（18）式となる。

$$
\begin{aligned}
& \left\{S_{Z}\left(f_{P}\right)+N_{B}+N_{W}\right\} /\left\{N_{D . Z}+N_{B}+N_{W}\right\} \geq 10 \\
& S_{Z \max }\left(f_{P}\right)(1-10 d)\left\{(Z / Z \max )^{-2}-1\right\} \geq 9 N w \\
& \therefore \quad(Z / Z \max )^{-2}-1 \geq C^{\prime} U^{\eta} \quad \ldots \ldots \ldots(1
\end{aligned}
$$

（1８）式より, 各高度でのデー夕取得可能な限界風速の比 $k$ を求 めて, 図 16 に示した。高度が上がるにつ机て, 限界風速が莪減す ること, 寸なわち, 高風速時のデー夕取得の困難さが窺わ机る。

\section{4 データ取得率と風速観測值の期待值}

高度 $Z_{0}$ でデー夕取得率が $100 \%$ になる風速の上限値を $U_{Z}$ O m m ax とすると, 平均風速観測值 $U_{Z O}$ の期待值は真值 $\mathrm{U}_{Z 0}$ に一致する。

$$
E[\beta]=1, \quad E\left[U_{\% 0}\right]=U_{z, \max }=U_{z 0}
$$

この時，任意高度 $Z\left(>Z_{0}\right)$ では，図 17 のようになり，

$$
\begin{aligned}
& E[\beta]=\int_{0}^{u z \cdot \max } f\left(u_{z}\right) d u_{z}<1 \\
& E\left[U_{z}\right]=\int_{0}^{u_{z, \max }} u_{z} f\left(u_{z}\right) d u_{z}<U_{z}
\end{aligned}
$$

高度 $Z$ でも後方散乱波のピークのパワーと平均パワーの比が一定

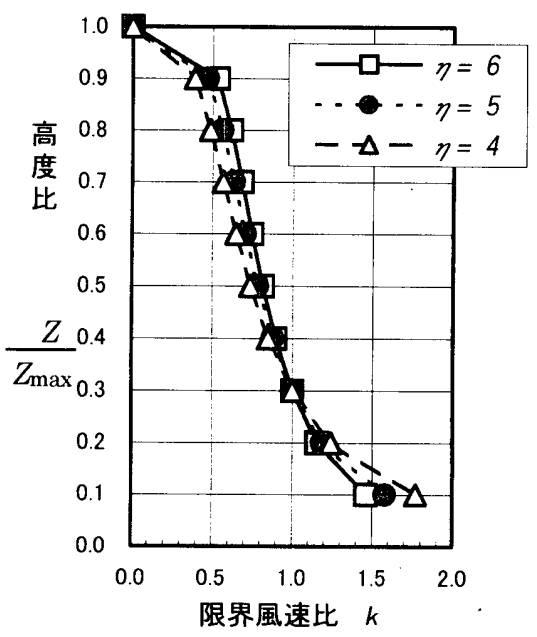

図 16 限界風速の試算結果 $\left(Z / Z_{\max }=0.3\right.$ での限界風速を 1 として表示した)

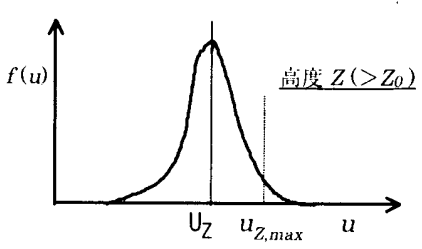

デー夕取得汀能な風速 $\rightarrow$

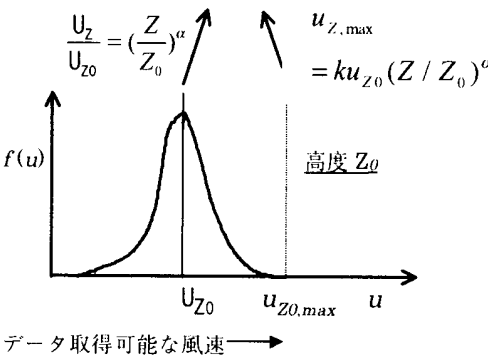

図 17 変動風速の確率分布 $f(u)$ と 限界風速 $U Z$, max

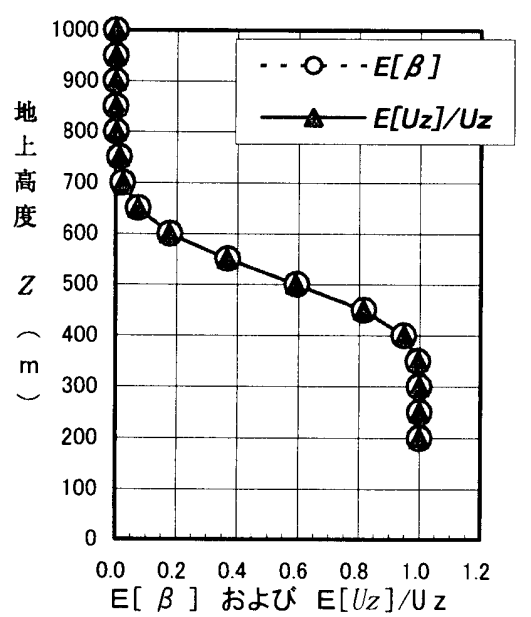

図 18 データ取得率 $\beta$ と平均風速観測値 の期待値 $\mathrm{E}[U z]\left(Z_{\max }=1000 \mathrm{~m}\right.$, $Z_{0}=300 \mathrm{~m}$, 粗度区分 II の場合) 
明らかに，観測値 $U_{Z}$ の期待值は真值 $U_{Z}$ を下回る。ここで， $u_{Z}=U_{Z}+u_{Z}{ }^{\prime}$ と書き, $f\left(u_{z}{ }^{\prime} / \sigma_{Z}\right)=f\left(u_{z 0}{ }^{\prime} / \sigma_{Z 0}\right)$ と仮定すると,

$$
E[\beta]=\int_{-g}^{\varepsilon} f\left(u_{Z}{ }^{\prime} / \sigma_{Z}\right) d\left(u_{Z 0}{ }^{\prime} / \sigma_{Z 0}\right)
$$

$E\left[U_{Z}\right]=U_{Z} \int_{-g}^{\varepsilon} f\left(u_{Z}{ }^{\prime} / \sigma_{Z}\right) d\left(u_{Z}{ }^{\prime} / \sigma_{Z}\right)+\sigma_{Z} \int_{-g}^{\varepsilon}\left(u_{Z}{ }^{\prime} / \sigma_{Z}\right) f\left(u_{Z}{ }^{\prime} / \sigma_{Z}\right) d\left(u_{Z}{ }^{\prime} / \sigma_{Z}\right)$

$$
<U_{Z} \int_{-y}^{\varepsilon} f\left(u_{Z}{ }^{\prime} / \sigma_{Z}\right) d\left(u_{Z}{ }^{\prime} / \sigma_{Z}\right)=U_{Z} \cdot E[\beta]
$$

ただし, $g=-u_{Z, \min }{ }^{1} / \sigma_{Z}, \quad \varepsilon=u_{Z \text { max }}{ }^{1} / \sigma_{\%}<g$ である。変 動風速の確率分布を正規分布と仮定すると，(24)式となる。

$$
E\left[U_{Z}\right]=U_{Z}\left\{E[\beta]-\left(\sigma_{Z} / U_{Z}\right) e^{-\varepsilon^{2} / 2} / \sqrt{2 \pi}\right\}
$$

したがって，観測值の期待値は，高々，真値に取得率の期待值を掛 けた程度であることになる。ここで，

$$
\begin{aligned}
& U_{Z}=U_{Z 0}\left(Z / Z_{0}\right)^{\alpha}, u_{Z}=u_{Z 0}\left(Z / Z_{0}\right)^{\alpha^{\prime}} \\
& I_{Z}=0.1\left(Z / Z_{(i}\right)^{-\alpha-0.05}
\end{aligned}
$$

とすると, ( 26 ) 式が導か札る。

$$
\varepsilon=10\left(Z / Z_{G i}\right)^{\alpha+0.05}\left\{k\left(Z / Z_{0}\right)^{\alpha^{\alpha-\alpha}}-1\right\}+k g_{\% 0}\left(Z / Z_{0}\right)^{0.05}\left(Z / Z_{0}\right)^{\alpha}
$$

ここで， $k$ は高度 $Z_{0}$ および $Z$ における限界風速の比である。さら に $\alpha^{\prime}=\alpha$ と仮定して, (2 6)，(22)，(24)式より, $\varepsilon, E[\beta]$, $\mathrm{E}\left[U_{Z}\right] / U_{Z}$ を試算した例を図 18 に示した。高度 $Z_{0}$ を超えると，デ 一夕取得率と観測值の期待值は急激に低下することが分かる。

\section{5 風速プロファイルへの影霓}

ドップラーソーダの観測值に対する風騒音の影響について，単純 化したモデルによる試算を行った。この結果によ机ば，風速か増す につれて，高高度でのデー夕取得率は莪減し，そ狄に伴い，選別集 計した高高度における風速観測値は真值よりも小さく評価される傾 向があることが分った。このように，風騷音の影響は無視できず， また，系統的な誤差をもたらすので，観測される風速プロファイル の形状もその影響を受ける可能性がある。したがって，風速のプロ ファイルを評価する際には，この点についても考慮が必要である。

\section{6 おわりに}

ドップラーソーダを用いた自然風観測結果から，風速のプロファ イルを求める場合の問題点を検討した。高高度までの風速を観測す るための適切な観測条件, 真の風速プロファイルに相当する風速が 時空間平均值として採取されるドップラーソーダの観測值から得ら れるかどうかの検討，および，風速レベルごとに風速プロファイル を推定する際に，風速レベル分けをするためのデー夕選別方法によ る推定結果への影響に関する検討，風速とともに増大すると考えら 扎る風騒音による観測值と風速プロファイルへの影響に関する検討 である。その結果，次のような事柄が明らかになった。

(1) 高度 $500 \mathrm{~m}$ 程度までの高度範囲の風速を観測するには，ドップ ラーソーダの送信条件は, 短パルス幅が 50 - 80msec, 長パルス幅が $300 \sim 500 \mathrm{msec}$ の混合パルス方式とし, 送信周波数は $2400 \mathrm{~Hz}$ とす るのが最も適切である。送信パワーは大きくする方が良い。

(2) ドップラーソーダの観測值はある空間領域の平均値であり，各
高度での局所的な風速ではないが，十分な精度の観測值が得られれ ば，その風速プロファイルは真のプロファイルに近いものになる。

(3) ドップラーソーダによる測定高度は, 音波の距離減衰を考慮し て，補正する必要がある。

(4) 代表高度における風速によりデー夕を選別・集計する方法は, 当該高度付近で真のプロファイルを歪める恐扎があり，風速プロフ アイルを求める方法として適切ではない。このような影響を取り除 くには全高度の平均風速によって選別・集計する方法が望ましい。

（5）強風になると風騷音の影響が大きくなり, 高高度でのデー夕取 得率が徐々に逢減し, 測定可能な高度が低下寸る。これに伴って, 風騒音の影響を受けた風速観測値の期待値はデー夕取得率の平均値 とともに低減すると推定される。したがって，得られる風速プロフ アイルの形状も，風騒音の影響を受ける可能性がある。

謝辞 本研究は大気境界層研究会において 1994年9月から実施して いる。本論文の内容は, 本研究会の議論に基づいていることを記し, 謝意を表します。著者のほかのメンバーは次の通りである。

藤井邦雄（風環境リサーチ），宮下康一(風工学研究所），小林 康之・佐々木亮治（西松建設），上江州清（都市基盤整備公団）

\section{【参考文嗝】}

1) 天野輝久, 大熊武司,川口彰久,後藤暁:ドップラーソーダによる沖縄 に掞ける台風時の風観測値, 日本風工学会誌, 第 67 号, pp.9-14,1996

2 ) 鄭永培, 神田順,内藤玄一,高倉秀一:市街地に扔ける複数ドップラー ソーダによる上空風観測, 日本建築学会大会学術講演梗概 集,pp.111-112,1996

3 ) 高倉秀一,赤林伸一,須川喜実：音波を利用した市街地上空の風の観 測 沿岸部 (新潟书) 及び内陸部（新津市）の市街地におりる鉛直 プロファイルの測定結果, 日本風工学会誌, 第 62 号, pp.35-44,1995

4 ) 日比一喜,神田順,桂順治：ドップラーソーダによる台風時の風速鉛 直分布の実測, 日本建築学会大会学術講演梗概集 B-1, pp.121-122, 1994

5 ) 須田健一,佐々木淳,藤井邦雄,小林康之,上江州清,田村幸雄：ドップ ラーソーダを用いた地表付近の平均風速の鉛直分布に関する研究， 第 14 回風工学シンポジウム論文集, pp.7-14,1996

6 ) 伊藤芳樹, 渡辺好弘, 水越利之, 花房龍男, 吉川友章, 内藤恵吉, 小平信 彦：ドップラーソーダの開発と大気境界層観測への応用,天気,第 33 号,第 8 号,pp.19-29,1986

7 ) 須田健一,小林康之, 藤井邦雄, 岩谷祥美,佐々木淳, 石橋龍吉,田村幸 雄:ドップラーソーダを用いた地表面粗度の異なる地点の風速鉛直 分布に関する研究(その1 平均風速鉛直分布の評価方法に関する検 討), 日本風工学会誌,第 71 号,pp.39·40,1997

8 ) 石橋龍吉,藤井邦雄,佐々木淳,須田健一, 日比一喜,田村幸雄：ドップ ラーソーダを用いた地表面粗度の異なる地点の風速鉛直分布に関す る研究（その 10 海岸での自然風観測結果），日本建築学会大会学 術講演梗概集 B-1,pp.235-236,1998

9 ) 中村修, 小林康之, 佐々木淳, 藤井邦雄, 須田健一, 石橋龍吉,田村幸雄 : ドップラーソーダを用いた地表面粗度の異なる地点の風速鉛直分布 に関する研究（その 11 沿岸住宅地での自然風観測結果），日本建 築学会大会学術講演梗概集 B·1,pp.237-238,1998

10) Lighthill, M.J. : On sound generated aerodynamically, I. General theory, Proc. R. Soc. London, A211, pp.564-587, 1952

(2001年4 月25日原稿受理，2001年 7 月 19 日採用決定） 